Jurnal Geocelebes Vol. 5 No. 2, Oktober 2021, 116 - 130

\title{
FAKTOR OSEAN - ATMOSFER UNTUK MEMPREDIKSI TITIK PANAS (HOTSPOT) DI WILAYAH ASIA TENGGARA BAGIAN SELATAN
}

\author{
Santriwati*, Halmar Halide, Hasanuddin \\ Departmen Geofisika, FMIPA, Universitas Hasanuddin, Makassar, Indonesia \\ *Corresponding author. Email: santrisw@gmail.com
}

Manuscript received: 2 April 2021; Received in revised form: 29 July 2021; Accepted: 9 August 2021

\begin{abstract}
Abstrak
Penelitian ini bertujuan untuk membuat pemodelan prediksi titik panas (hotspot) di wilayah Asia Tenggara bagian Selatan dengan sejumlah prediktor signifikan menggunakan Model Multiple Regression (MR) dan untuk melakukan verifikasi prediksi model tersebut. Data yang digunakan dalam penelitian ini yaitu data observasi titik panas (hotspot) di Wilayah Indonesia yakni di Pulau Kalimantan dan Sumatera dan di Wilayah Semenanjung Malaysia serta Sabah-Sarawak. Kemudian data indeks El Nino Southern Oscillation (ENSO), Madden-Julian Oscillation (MJO), Indian Ocean Dipole (IOD) dan Monsun selama 6 tahun mulai dari tahun 2013 hingga 2018 sebagai data prediktor. Metode yang digunakan yaitu Model Multiple Regression dengan Metode Regresi Stepwise dan verifikasi skill model prediksi yang digunakan yaitu Korelasi Pearson dan RMSE. Berdasarkan hasil pemodelan dan verifikasi prediksi terbaiknya, diperoleh nilai Korelasi Pearson sebesar 0,698 dan nilai RMSE-nya sebanyak 908 hotspot. Untuk model prediksi di wilayah Sumatera oleh 7 prediktor signifikan yang terkait dengan kejadian hotspot yaitu, IOD 0 (IOD pada bulan munculnya hotspot), MJO 0, MJO 9, MJO 10, Mons 1, MJO 8, dan MJO 5. Untuk wilayah Kalimantan nilai Korelasi Pearson sebesar 0,795 dan nilai RMSE-nya sebanyak 1150 hotspot oleh 4 prediktor signifikan, MJO 9 (MJO pada 9 bulan sebelum munculnya hotspot), Mons 1, Mons 0, dan ENSO 3. Untuk wilayah Semenanjung Malaysia diperoleh nilai Korelasi Pearson sebesar 0,145 dan nilai RMSE-nya sebanyak 135 hotspot oleh 2 prediktor signifikan, Mons 2 (Mons pada 2 bulan sebelum munculnya hotspot) dan MJO 0. Kemudian untuk wilayah Sabah dan Sarawak diperoleh nilai Korelasi Pearson sebesar 0,242 dan nilai RMSE-nya sebanyak 113 hotspot oleh 2 prediktor signifikan, IOD 2 (IOD pada 2 bulan sebelum munculnya hotspot) dan MJO 0. Untuk wilayah Sumatera prediktor yang paling berpengaruh yaitu IOD 0, yakni fenomena IOD khususnya fenomena IOD (+) penyebab terjadinya musim kering ini beberapa kali terjadi di wilayah Pulau Sumatera karena letaknya berdekatan langsung dengan Samudera Hindia sehingga iklimnya juga dipengaruhi oleh lautan di dekatnya. Untuk fenomena MJO dan Monsun yang paling berpengaruh di Wilayah Kalimantan (MJO 9), Semenanjung Malaysia (Mons 2) serta Sabah Sarawak (MJO 0). Kedua fenomena tersebut secara periodik selalu melintas di ketiga wilayah tadi khususnya berkontribusi pada bulan-bulan terjadinya musim kering, sehingga diindikasikan dapat mempengaruhi munculnya hotspot.
\end{abstract}

Kata Kunci: Asia Tenggara bagian Selatan; osean-atmosfer; pemodelan prediksi; Titik Panas; verifikasi prediksi.

\begin{abstract}
The purpose of this research is to make prediction modeling on hotspots in Southeast Asia in the Southern Region with several significant predictors using the Multiple Regression (MR) Model and verify the model's predictions. The data used in this study is the observation data onto hotspots in the
\end{abstract}


Indonesian Territory, namely on the islands of Kalimantan and Sumatra and in the Peninsular Malaysia and Sabah-Sarawak Region. Then the El Niño Southern Oscillation (ENSO), Madden-Julian Oscillation (MJO), Indian Ocean Dipole (IOD), and Monsoon index data for 6 years from 2013 to 2018 as predictor data. The method used is the Multiple Regression Model with the Stepwise Regression Method and the verification of the prediction model skills used is the Pearson Correlation and RMSE. Based on modeling and verifying the best predictions, the Pearson Correlation value is 0.698 and the RMSE value is 908 hotspots. For the prediction model in the Sumatra region, by 7 significant predictors related to hotspot events, namely, IOD 0 (IOD in the month the hotspot appears), MJO 0, MJO 9, MJO 10, Mons 1 , MJO 8, and MJO 5. Prediction model in Kalimantan region, pearson's correlation is 0.795 and its RMSE value is 1150 Hotspots by 4 significant predictors, MJO 9 (MJO at 9 months before the emergence of hotspots), Mons 1, Mons 0, and ENSO 3. For the Peninsular Malaysia region, the Pearson Correlation value is 0.145 and The RMSE value is 135 Hotspots by 2 significant predictors, Mons 2 (Mons at 2 months before hotspots emerge) and MJO 0. Then for the Sabah and Sarawak regions, the Pearson Correlation value is 0.242 and the RMSE value is 113 hotspots by 2 predictors. significantly, IOD 2 (IOD at 2 months before the hotspots emerge) and MJO 0. For the Sumatra region, the most influential predictor is IOD 0 , where the IOD phenomenon, especially the IOD $(+)$ the phenomenon causes the dry season. This has happened several times in the area of Sumatra Island because it is located directly next to the Indian Ocean, so that the climate is also influenced by the ocean near it. For the MJO and Monsoon phenomena which are the most influential in the Kalimantan Region (MJO 9), Malaysia Peninsula (Mons 2), and Sabah - Sarawak (MJO 0). These two phenomena periodically always cross these three areas, especially contributing to the dry season months, so that it can affect hotspots emerge.

Keywords: atmospheric oceanic; hotspot; predictive modeling; prediction verification; Southeast Asia.

\section{Pendahuluan}

Bencana kebakaran hutan dan lahan (Karhutla) di Indonesia merupakan salah satu permasalahan yang rutin dan terjadi setiap tahun khususnya pada musim kemarau. Karhutla di Indonesia dalam skala besar pernah terjadi tahun 1982-1983, 1991, 1994, 1997-1998, 2006. Pada tahun 2015, kebakaran hutan terjadi di wilayah Sumatera, Kalimantan, dan Papua yang telah menyebabkan $80 \%$ wilayah Sumatera dan Kalimantan tertutup asap pekat. Dampak kebakaran hutan paling terasa pengaruhnya di bidang ekonomi dan sosial masyarakat secara nasional dan juga mempengaruhi beberapa negara di kawasan Asia Tenggara khususnya negara tetangga yaitu Singapura dan Malaysia (Endrawati, 2016).

Karhutla menjadi bencana rutin di Indonesia yang terjadi hampir setiap tahunnya terkhusus di pulau Sumatera dan Kalimantan menjadi wilayah yang paling sering dilanda dan memiliki dampak yang sangat parah (Prayoga dkk., 2017). Di dalam dokumen Grand Design Pencegahan Karhutla yang dikeluarkan oleh Bappenas, dijelaskan dalam periode 15 tahun terakhir, 2000-2015, puncak titik panas melebihi 15.000 terjadi pada tahun 2002, 2004, 2006, 2009, 2014 dan 2015 (Bappenas, 2016). Adapun indikator yang dapat digunakan sebagai deteksi awal bencana Karhutla adalah Titik Panas (Hotspot), namun suatu hotspot belum tentu memiliki titik api atau kebakaran hutan. Hotspot dapat mengindikasikan kemungkinan adanya kebakaran hutan apabila semakin banyak hotspot yang muncul dan berdekatan di suatu wilayah (BNPB, 2013).

Karhutla biasanya terjadi karena faktor manusia, yaitu kesengajaan membakar, membuka lahan baru, buruknya pengelolaan ekosistem rawa gambut, didukung musim kemarau panjang akibat El Nino serta lemahnya pengawasan (Erwinsyah, 2017). Kondisi iklim di Indonesia secara geografis dipengaruhi oleh fenomena interaksi laut dan atmosfer seperti El Nino/ La Nina yang bersumber dari wilayah timur Indonesia dan Dipole 
Mode yang bersumber dari wilayah barat Indonesia. Ada juga fenomena regional yang mempengaruhi seperti sirkulasi monsun Asia-Australia serta kondisi topografi wilayah Indonesia yang cukup beragam (BNPB, 2013).

Sebagai Early Warning System untuk membantu mengantisipasi kerugiankerugian yang timbul akibat bencana kebakaran hutan dan lahan, maka penelitian mengenai prediksi titik panas (hotspot) dapat dilakukan dengan pemodelan analisis statistik. Penelitian ini bertujuan untuk melakukan pemodelan prediksi titik panas (hotspot) di wilayah Asia Tenggara bagian Selatan dengan sejumlah prediktor signifikan seperti indeks MJO, ENSO, IOD, Monsun dengan analisis pemodelan Multiple Regression (MR) dengan Metode Regresi Stepwise. Kemudian melakukan verifikasi model prediksi tersebut.

\section{Titik Panas (Hotspot)}

Titik Panas (Hotspot) adalah indikator dari kebakaran hutan yang digunakan untuk mendeteksi suatu lokasi yang memiliki suhu relatif lebih tinggi dibandingkan dengan suhu disekitarnya (Permenhut No. P.12/Menhut-II/2009). Berdasarkan kesepakatan dari negara-negara anggota ASEAN bahwa penentuan ambang batas panas didefinisikan sebagai hotspot apabila mencapai $321^{\circ} \mathrm{K}\left(48^{\circ} \mathrm{C}\right)(\mathrm{BNPB}, 2013)$.

Hotspot biasanya digunakan sebagai indikator awal untuk mendeteksi kemungkinan terjadinya kebakaran hutan di suatu wilayah, apabila semakin banyak jumlah titik panas yang muncul, maka semakin besar pula potensi kebakaran hutan dan lahan yang terjadi di suatu wilayah. Walaupun tidak selamanya semakin banyak hotspot pada suatu wilayah semakin banyak pula potensi kejadian kebakaran. Namun hotspot dapat digunakan sebagai acuan untuk melakukan identifikasi awal kejadian kebakaran hutan dan lahan (Endrawati, 2016).

\section{El Niño Southern Oscillation (ENSO)}

El Nino-Southern Oscillation (ENSO) atau yang biasa dikenal dengan El Nino merupakan fenomena yang ditimbulkan oleh interaksi laut atmosfer. El Nino adalah suatu gejala alam di Samudra Pasifik bagian tengah dan timur yaitu memanasnya suhu permukaan laut di wilayah tersebut. Pada saat yang bersamaan terjadi perubahan pola tekanan udara yang mempunyai dampak sangat luas dengan gejala yang berbeda-beda, baik bentuk dan intensitasnya (Mulyana, 2002). Komponen laut dari ENSO adalah fenomena El Nino, sedangkan komponen atmosfernya adalah Southern Oscillation. Pusat aktivitas ENSO berada di Samudra Pasifik yang berdekatan dengan garis ekuator (Hacker and Hastenrath, 1985).

Kejadian ENSO dapat menyebabkan perubahan iklim pada daerah Tropis Pasifik yang mempengaruhi sirkulasi atmosfer global (Trenberth, 1997). Salah satu dampak yang ditimbulkan oleh kejadian ENSO di musim kering sebagian besar dilanda oleh bencana kebakaran hebat seperti kebakaran yang terjadi pada bulan Agustus-Oktober 2002 dan pencemaran berat kabut asap di Kalimantan dikaitkan dengan kejadian ENSO berkekuatan sedang (Tacconi, 2003).

\section{Madden-Julian Oscillation ( $M J O)$}

Madden-Julian Oscillation (MJO) pertama kali ditemukan oleh peneliti Ronald A. Madden dan Paul R. Julian pada tahun 1971, mereka menemukan semacam osilasi gelombang yang berperiode sekitar 41-53 hari pada saat menganalisis anomali angin zonal di wilayah Pasifik tropis dengan menggunakan data tekanan 10 tahun $\mathrm{P}$. Canton (2 $8^{\circ}$ " LS - 171 ${ }^{\circ}$ " BB) dan data angin lapisan atas Singapura (Madden dan Julian, 1994).

MJO berpengaruh terhadap proses konveksi yang terjadi di wilayah yang dilaluinya. Pengaruh aktivitas MJO dapat 
dideteksi dari besarnya nilai indeks dari anomali Outgoing Longwave Radiation (OLR) yang terjadi. Semakin negatif nilai OLR yang terbentuk di suatu wilayah mengindikasikan semakin banyaknya liputan awan yang menutupi wilayah tersebut. Sebaliknya, semakin besar nilai OLR positif yang terbentuk di suatu wilayah menunjukkan semakin sedikit liputan awan yang ada di wilayah tersebut (BMKG, 2017). Fenomena MJO sangat mempengaruhi cuaca dan iklim secara global (Maloney and Hartmann, 2000). MJO diketahui memodulasi aktivitas terbentuknya siklon tropis di Samudera Hindia, Samudera Pasifik, Teluk Meksiko, dan Samudra Atlantik. Karena aktivitas MJO berlangsung ke arah timur, maka wilayah aktvitas siklon tropis juga bergeser ke arah timur dari Samudera Hindia ke Samudera Pasifik dan akhirnya ke Samudera Atlantik (Madden and Julian, 1994).

\section{Indian Ocean Dipole $(I O D)$}

Fenomena Indian Ocean Dipole (IOD) merupakan fenomena yang terbentuk dari interaksi yang cukup kuat antara atmosfer dan lautan di wilayah Samudera Hindia, atau dapat juga didefinisikan sebagai gejala ataupun tanda-tanda menaiknya suhu permukaan laut yang tidak normal di Samudera Hindia sebelah selatan India yang diiringi dengan menurunnya suhu permukaan laut tidak normal di perairan Indonesia, tepatnya di sekitar wilayah Barat Sumatera (Saji and Yamagata, 2003). Indikator yang digunakan untuk mengetahui kejadian IOD adalah Dipole Mode Index (DMI), yaitu perbedaan anomali Sea Surface Temperature (SST) antara Bagian Barat $\left(10^{\circ} \mathrm{LU}-10^{\circ} \mathrm{LS} ; 60^{\circ} \mathrm{BT}-\right.$ $\left.80^{\circ} \mathrm{BT}\right)$ dan Timur $\left(0^{\circ}-10^{\circ} \mathrm{LS}\right.$; $90^{\circ} \mathrm{BT}-$ $110^{\circ} \mathrm{BT}$ ) dari Samudera Hindia (Saji et al., 1999).

Proses IOD positif dimulai pada bulan MeiJuni ditandai dengan munculnya anomali SPL negatif (SPL dingin) di sekitar Selat Lombok. Selanjutnya pada bulan Juli-
Agustus, anomali negatif SPL tersebut terus menguat dan berpindah tempat menuju equator sepanjang garis pantai Indonesia, sementara itu dibagian barat Samudera Hindia mulai muncul anomali SPL positif (SPL bangat). Anomali angin sepanjang katulistiwa ini meningkat bersamaan dengan pengkutuban SPL. Sehingga terjadi pumpunan awan-awan konvektif berada di sekitar pantai timur Benua Afrika yang menyebabkan tingginya intensitas curah hujan di wilayah tersebut, sedangkan di wilayah Benua Maritim Indonesia bagian barat relatif rendah atau terjadi kekeringan. (Saji et al., 1999). Sebaliknya, Fase IOD negatif merupakan kebalikan dari IOD positif (Vinayachandran et al., 2002; lizuka et al., 2000).

\section{Monsun}

Monsun adalah angin yang bertiup sepanjang tahun dan terbentuk dari hasil interaksi langsung antara udara dan lautan dan salah satu dari fenomena atmosfer yang berosilasi sekitar 6-12 bulan terutama terjadi di daerah sekitar ekuator (Krishnamurti and Bhalme, 1976). Dampak dari fenomena monsun sangat mempengaruhi pola musim hujan dan kemarau di Wilayah Indonesia. Monsun merujuk pada siklus tahunan yang membedakan secara tegas keadaan atmosfer selama fase kering dan fase basah. Siklus tahunan ini membagi fase kering dan fase basah menjadi dua periode. Fase kering dipengaruhi oleh musim dingin yang terjadi di berbagai benua dengan massa udara di atmosfer yang bersifat dingin dan kering (Webster et al., 1998). Sebaliknya, fase basah dipengaruhi oleh musim panas dengan udara yang bersifat lembab (Chang et al., 2005).

\section{Metode Regresi Stepwise}

Metode Regresi Stepwise bekerja dengan memulai pemilihan dengan model yang paling sederhana yaitu model dengan satu peubah. Langkah selanjutnya disusupkan peubah lain satu persatu sampai diperoleh 
model yang memenuhi kriteria terbaik. Pendekatan analisis mengikuti tahapan dari regresi multivariat sebagai berikut (Fahrmeir et al., 2013):

$$
Y=\beta_{0}+\beta_{1} X_{1}+\beta_{2} X_{2}+\ldots+\beta_{k} X_{k}+\varepsilon
$$

dengan

Y $\quad$ : Variabel terikat (hotspot)

$\beta_{0} \quad$ : Konstanta regresi

$\beta_{1}, \beta_{2}, \ldots, \beta_{\mathrm{k}} \quad$ : Koefisien regresi

$\mathrm{X}_{1}, \mathrm{X}_{2}, \ldots, \mathrm{X}_{\mathrm{k}} \quad$ : Variabel bebas/ prediktor

(ENSO, MJO, IOD, dan Monsun)

$\varepsilon$

: Galat taksiran (sisa

residu)

\section{Verifikasi Prediksi Model Statistik}

Akurasi prediksi dari sebuah model berbanding lurus dengan hasil Korelasi Pearson-nya. Semakin besar nilai korelasinya maka semakin bagus pula akurasi prediksi sebuah model. Sedangkan pada root mean square error (RMSE), berbanding terbalik dengan Korelasi Pearson. Jika semakin kecil nilai RMSE atau semakin rendah nilai galatnya maka semakin bagus pula akurasi prediksi sebuah model (Nur, 2017). Untuk nilai korelasi dibawah 0,5 akan dianggap bahwa kemampuan prediksi oleh suatu model tidak dapat dipakai (Nur, 2017).

\section{Metode Penelitian}

\section{Data Penelitian}

Data yang digunakan pada penelitian ini merupakan data sekunder yang terdiri dari data Titik Panas (Hotspot) yang diperoleh dari situs ASMC, ENSO (Nino 3.4), Madden-Julian Oscillation (MJO), Indian Ocean Dipole (IOD) dan data Monsun mulai dari tahun 2013 sampai dengan tahun 2018 yang diperoleh dari situs NOAA dan KNMI Climate Explorer. Alat yang digunakan untuk memodelkan data dalam penelitian ini adalah software pengolahan data.
Tahap Pengolahan Data

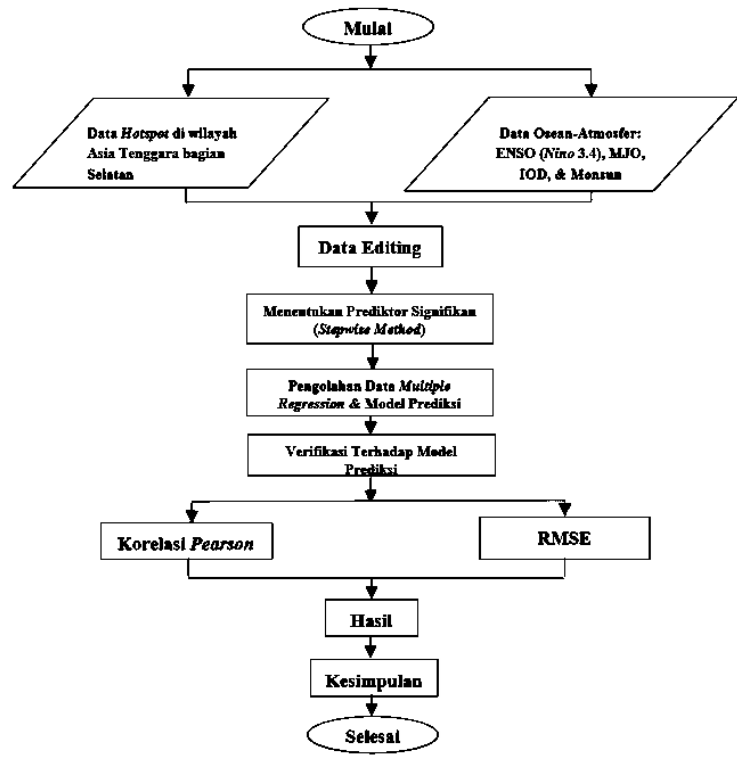

Gambar 1. Bagan Alir Penelitian

Berikut merupakan tahap pengolahan data (Gambar 1):

1. Mengumpulkan data penelitian yaitu data observasi hotspot di Wilayah Asia Tenggara bagian Selatan yang mencakup wilayah Pulau Kalimantan dan Sumatera di Indonesia, Wilayah Semenanjung dan Sabah-Sarawak di Malaysia sesuai yang tercantum dan tersedia di situs resmi ASMC, kemudian data indeks ENSO, MJO, IOD, dan Monsun sebagai data prediktor.

2. Melakukan pemeriksaan kembali (editing) data penelitian yang diperoleh dari hasil unduh secara manual untuk menghindari kesalahan pengetikan dalam mengolah sejumlah data yang cukup banyak. Mengolah data hotspot dan data prediktor, menggunakan analisis model multiple regression (MR) dengan metode regresi stepwise untuk mengetahui prediktor yang berpengaruh terhadap munculnya hotspot.

3. Mengidentifikasi dan menentukan sejumlah prediktor signifikan yang berpengaruh terhadap munculnya hotspot berdasarkan perolehan hasil metode regresi stepwise.

4. Memodelkan hasil prediksi hotspot yang telah diperoleh, dengan data observasi 
hotspot dalam bentuk grafik dan diagram tebar.

5. Melakukan verifikasi prediksi model, pada tahap in data prediksi hotspot diverifikasi dengan sejumlah prediktor signifikan menggunakan kemampuan deterministik yaitu dengan menghitung nilai Korelasi Pearson dan RMSE.

6. Analisa hasil berdasarkan faktor interaksi osean-atmosfer pada lokasi penelitian.

\section{Hasil dan Pembahasan}

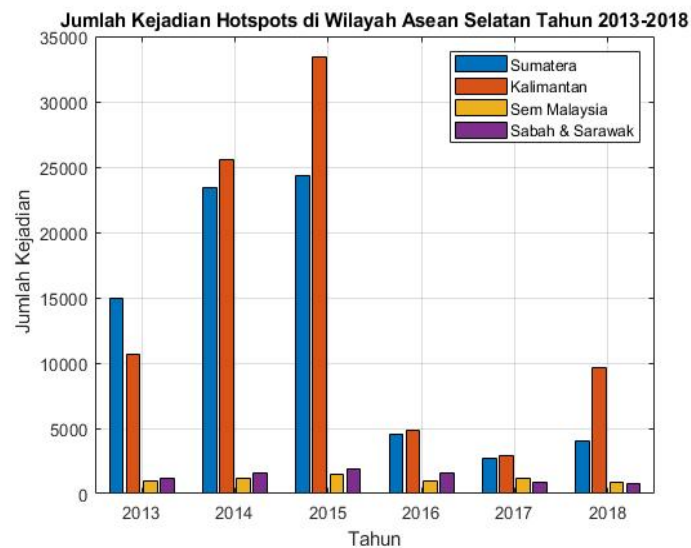

Gambar 2. Grafik jumlah kejadian munculnya hotspot selama 6 Tahun (2013-2018).

Gambar 2 merupakan gambar grafik yang memperlihatkan jumlah kejadian titik panas (hotspot) di Kawasan Asia Tenggara bagian Selatan dalam rentang waktu tahun 2013 sampai pada tahun 2018. Data diperoleh dari situs ASMC (Asean Spealized Meteorological Center) yang terdiri dari 2 negara yaitu Indonesia di wilayah Sumatera dan Kalimantan serta Malaysia di wilayah Semenanjung dan Sabah dan Sarawak. Berdasarkan grafik tersebut dapat dilihat bahwa kejadian hotspot terparah terjadi pada tahun 2015 dengan wilayah Kalimantan yang memiliki jumlah hotspot terbanyak yang mencapai 35.000 titik panas (hotspot).

Prediktor Signifikan terhadap Prediksi Titik Panas (otspot) di Wilayah Pulau Sumatera

Dengan menggunakan metode regresi stepwise memberikan hasil prediktor yang signifikan yang paling berpengaruh terhadap prediksi hotspot. Prediktor yang digunakan sebanyak 49 yang terdiri dari 13 prediktor ENSO (Nino 3.4), 13 prediktor Madden-Julian Oscillation (MJO), 13 prediktor Indian Oscillation Dipole (IOD), dan 9 prediktor Monsun. Pada hasil ini ada beberapa istilah (singkatan) yang digunakan pada tiap prediktor untuk memudahkan dalam mengenalinya. Pada prediktor ENSO (Nino 3.4) diberi istilah ENSO, prediktor MJO dan IOD menggunakan singkatannya sendiri, serta prediktor Monsun diberi istilah Mons.

Tabel 1. Nilai koefisien dan signifikan beberapa prediktor osean-atmosfer di Pulau Sumatera.

\begin{tabular}{ccccc}
\hline No & Prediktor & Koefisien & $\begin{array}{c}\text { Koefisien } \\
\text { standar } \\
\text { (Beta) }\end{array}$ & Signifikan \\
\hline 1 & IOD 0 & $-1244,90$ & $-2,02$ & 0,001 \\
2 & MJO 9 & 1069,00 & $-0,99$ & 0,000 \\
3 & MJO 0 & $-896,09$ & 0,95 & 0,000 \\
4 & MJO 10 & $-804,48$ & $-0,89$ & 0,002 \\
5 & Mons 1 & 598,53 & 0,49 & 0,007 \\
6 & MJO 8 & $-510,38$ & $-0,49$ & 0,041 \\
7 & MJO 5 & 475,37 & 0,46 & 0,048 \\
\hline \multicolumn{7}{c}{ Konstanta } & 1037,6 & & 0,000 \\
\hline
\end{tabular}

$\mathrm{Y}=\mathrm{a}+(-804,48 \times \mathrm{MJO} 10)+(896,09 \times \mathrm{MJO}$ $9)+(-510,38 \times \mathrm{MJO} 8)+(475,37 \times \mathrm{MJO} 5)+$ $(1069,00 \times \mathrm{MJO} 0)+(-1244,90 \times \mathrm{IOD} 0)+$ $(589,53 \times$ Mons 1$)$

dengan:

Y : Jumlah kemunculan hotspot tiap bulan

a : Konstanta

IOD 0 : IOD pada bulan munculnya hotspot

MJO 0 : MJO pada bulan munculnya hotspot

MJO 9 : MJO pada 9 bulan sebelum munculnya hotspot

MJO 10: MJO pada 10 bulan sebelum munculnya hotspot

Mons 1 : Mons pada 1 bulan sebelum munculnya hotspot

MJO 8 : MJO pada 8 bulan sebelum munculnya hotspot

MJO 5 : MJO pada 5 bulan sebelum munculnya hotspot 
Berdasarkan prediktor yang digunakan menghasilkan tujuh prediktor signifikan yang memiliki nilai signifikansi kurang dari 0,05. Pada Tabel 1. dapat dilihat prediktor dengan nilai koefisien standar (beta) berturut-turut, yaitu IOD 0, MJO 0, MJO 9, MJO 10, MJO 8, Mons 1, dan MJO 5 dengan nilai Korelasi Pearson sebesar 0,698 .

Berdasarkan perolehan 7 prediktor yang signifikan adalah diantaranya prediktor IOD 0 yang memiliki nilai koefisien standar (beta) paling besar yaitu -2,02 dalam hal ini berarti prediktor tersebut diindikasikan paling memengaruhi terkait kejadian munculnya hotspot.

Untuk prediktor MJO 0, MJO 9 dan MJO 8 memiliki nilai beta negatif yang menandakan hubungan antara ketiga prediktor tersebut dan hasil prediksi jumlah hotspot berbanding terbalik artinya semakin rendah nilai IOD 0 maka pengaruhnya untuk memprediksi hotspot akan semakin besar. Sedangkan tiga predikor lainnya, yaitu MJO 5, MJO 0, dan Mons 1 memiliki nilai koefisien standar (beta) yang positif artinya semakin besar nilai ketiga prediktor tersebut maka pengaruhnya untuk memprediksi hotspot akan meningkat juga.

Prediktor Signifikan terhadap Prediksi Titik Panas (otspot) di Wilayah Pulau Kalimantan

Tabel 2. Nilai koefisien dan signifikan beberapa prediktor osean-atmosfer di Pulau Kalimantan.

\begin{tabular}{|c|c|c|c|c|}
\hline No & Prediktor & Koefisien & $\begin{array}{c}\text { Koefisien } \\
\text { standar } \\
\text { (Beta) }\end{array}$ & Signifikan \\
\hline 1 & MJO 9 & $-1200,10$ & $-1,98$ & 0,000 \\
\hline 2 & ENSO 3 & $-1145,70$ & 1,29 & 0,000 \\
\hline 3 & Mons 1 & $-673,42$ & $-0,78$ & 0,005 \\
\hline \multirow[t]{2}{*}{4} & Mons 0 & 778,61 & $-0,56$ & 0,000 \\
\hline & Konstanta & 160,11 & & 0,500 \\
\hline $\begin{array}{l}Y \\
12 \\
67\end{array}$ & $\begin{array}{l}=\mathrm{a}+ \\
0,10 \times \mathrm{MJ} \\
, 42 \times \text { Mon }\end{array}$ & $\begin{array}{l}\text { (778,61 } \\
9)+(-1 \\
0)\end{array}$ & $\begin{array}{l}\mathrm{NSO} \\
5,70 \times \mathrm{N}\end{array}$ & $\begin{array}{r}+(- \\
\text { as } 1)+(- \\
(3)\end{array}$ \\
\hline
\end{tabular}

dengan:

Y : Jumlah kemunculan hotspot tiap bulan

a : Konstanta

MJO 9 : MJO pada 9 bulan sebelum munculnya hotspot

Mons 1 : Mons pada 1 bulan sebelum munculnya hotspot

Mons 0 : Mons pada bulan munculnya hotspot

ENSO 3: ENSO pada 3 bulan sebelum munculnya hotspot

Pada Tabel 2, berdasarkan 4 prediktor yang signifikan adalah diantaranya prediktor MJO 9 yang memiliki nilai koefisien standar (beta) paling besar yaitu $-1,98$ dalam hal ini berarti prediktor tersebut merupakan prediktor yang paling memengaruhi terkait kejadian kemunculan hotspot, karena nilai beta negatif maka hubungan antara prediktor MJO 9 dan hasil prediksi jumlah hotspot berbanding terbalik yang artinya semakin rendah nilai MJO 9 maka pengaruhnya untuk memprediksi hotspot akan semakin meningkat. Hal ini sama dengan yang terjadi pada prediktor Mons 1 dan Mons 0, sedangkan sisanya yaitu ENSO 3 memiliki nilai koefisien standar (beta) yang positif artinya semakin besar nilai prediktor ENSO 3 maka pengaruhnya untuk memprediksi hotspot akan meningkat juga.

Prediktor Signifikan terhadap Prediksi Titik Panas (otspot) di Wilayah Pulau Kalimantan

Tabel 3 adalah hasil nilai koefisien dan signifikan dari beberapa prediktor yang berpengaruh dalam memprediksi hotspot.

Tabel 3. Nilai koefisien dan signifikan beberapa prediktor osean-atmosfer di Semenanjung Malaysia.

\begin{tabular}{ccccc}
\hline No & Prediktor & Koefisien & $\begin{array}{c}\text { Koefisien } \\
\text { standar } \\
\text { (Beta) }\end{array}$ & Signifikan \\
\hline 1 & Mons 2 & 45,64 & 0,28 & 0,01 \\
2 & MJO 0 & 70,801 & 0,27 & 0,01 \\
\hline & Konstanta & 82,082 & & 0,000 \\
\hline
\end{tabular}

$\mathrm{Y}=\mathrm{a}+(70,801 \times \mathrm{MJO} 0)+(45,64 \times$ Mons 2$)$ 
dengan:

Y : Jumlah kemunculan hotspot tiap bulan

a : Konstanta

MJO 0 : MJO pada bulan munculnya hotspot

Mons 2 : Mons pada 2 bulan sebelum munculnya hotspot

Berdasarkan 2 prediktor yang signifikan adalah prediktor Mons 2 yang memiliki nilai koefisien standar (beta) paling besar yaitu 0,28 dalam hal ini berarti prediktor tersebut merupakan prediktor yang paling memengaruhi terkait kejadian kemunculan hotspot, karena nilai koefisien standar (beta) positif maka hubungan antara prediktor Mons 2 dan hasil prediksi Hotspot akan semakin besar. Hal ini sama dengan yang terjadi pada prediktor MJO 0.

Prediktor Signifikan terhadap Prediksi Titik Panas (otspot) di Wilayah Pulau Kalimantan

Tabel 4. Nilai koefisien dan signifikan beberapa prediktor osean-atmosfer di Wilayah Sabah dan Sarawak.

\begin{tabular}{ccccc}
\hline No & Prediktor & Koefisien & $\begin{array}{c}\text { Koefisien } \\
\text { standar } \\
\text { (Beta) }\end{array}$ & Signifikan \\
\hline 1 & MJO 0 & $-117,45$ & 0,43 & 0,01 \\
2 & IOD 2 & 99,616 & $-0,29$ & 0,01 \\
\hline & Konstanta & 115,85 & & 0,000 \\
\hline
\end{tabular}

$\mathrm{Y}=\mathrm{a}+(99,616 \times \mathrm{MJO} 0)+(-117,45 \times \mathrm{IOD}$

2)

dengan:

Y : Jumlah kemunculan hotspot tiap bulan

a : Konstanta

MJO 0 : MJO pada bulan munculnya hotspot

IOD 2 : IOD pada 2 bulan sebelum munculnya hotspot

Tabel 4 adalah hasil nilai koefisien dan signifikan dari beberapa prediktor yang berpengaruh dalam memprediksi hotspot.

Berdasarkan 2 prediktor yang signifikan adalah prediktor MJO 0 yang memiliki nilai koefisien standar (beta) paling besar yaitu 0,43 dalam hal ini berarti prediktor tersebut merupakan prediktor yang paling memengaruhi terkait kejadian munculnya hotspot, karena nilai beta positif maka hubungan antara prediktor MJO 0 dan hasil prediksi jumlah hotspot berbanding lurus yang artinya semakin tinggi nilai MJO 0 maka pengaruhnya untuk memprediksi hotspot akan semakin besar. Kemudian, untuk prediktor IOD 2 yang memiliki nilai koefisien standar (beta) negatif yang artinya semakin rendah nilai prediktor IOD 2 maka pengaruhnya untuk memprediksi hotspot akan semakin besar.

Model Pengaruh Prediktor OseanAtmosfer terhadap Hasil Prediksi Titik Panas (ㅎotspot) di Wilayah Asia Tenggara bagian Selatan

Model prediksi terbaik merupakan model yang mampu merepresentasikan besarnya presisi suatu prediksi apabila semakin banyak data prediksi yang berimpit dengan data observasi, namun sebaliknya jika semakin sedikit data prediksi yang berimpit dengan data observasi maka semakin kecil presisi suatu prediksi.

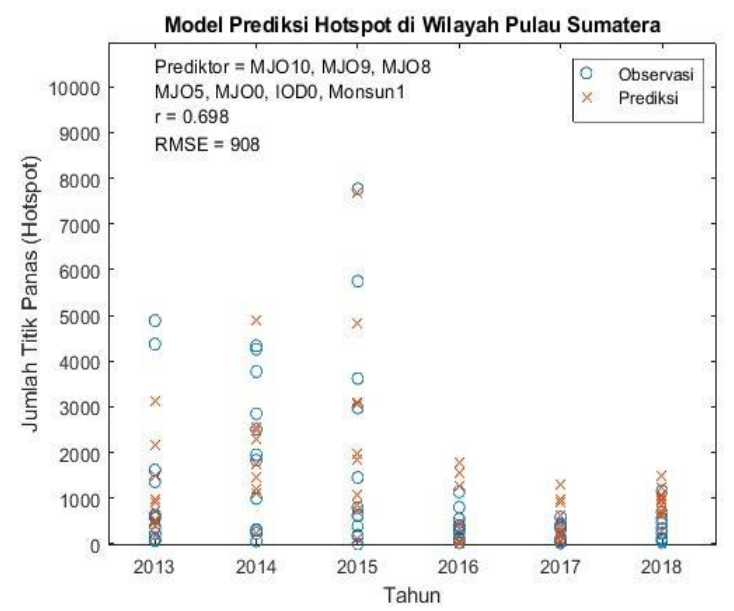

Gambar 3. Model prediksi titik panas (hotspot) di wilayah Pulau Sumatera.

Berdasarkan hasil pemodelan untuk wilayah Sumatera (Gambar 3), dari keempat jenis variabel bebas atau prediktor (Osean-atmosfer) yang digunakan dapat dilihat bahwa variabel MJO yang paling dominan berpengaruh terhadap munculnya 
hotspot diantaranya yaitu MJO 10, MJO 9, MJO 8, MJO 5, dan MJO 0 kemudian diikuti oleh pengaruh prediktor IOD 0 dan Monsun 1.

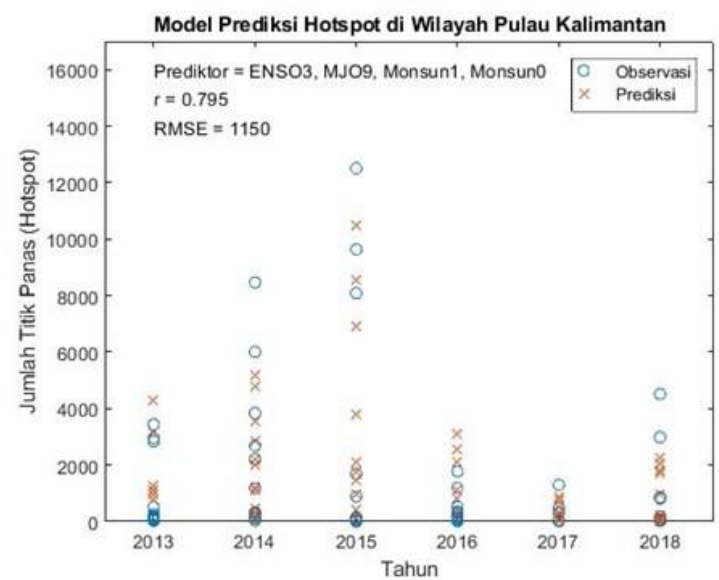

Gambar 4. Model prediksi titik panas (hotspot) di wilayah Pulau Kalimantan.

Pada Gambar 4, dari keempat jenis variabel bebas atau prediktor (Osean-atmosfer) yang digunakan dapat dilihat bahwa variabel Monsun dominan berpengaruh terhadap munculnya hotspot diantaranya yaitu Mons 1 dan Mons 0 kemudian diikuti oleh pengaruh prediktor ENSO 3 dan MJO 9.

Selanjutnya, dari kedua model prediksi wilayah Sumatera dan Kalimantan hanya beberapa range data prediksi dan data observasi hotspot yang berimpit (memiliki kesesuaian) dan sebagian besar tidak berimpit atau hampir mendekati.

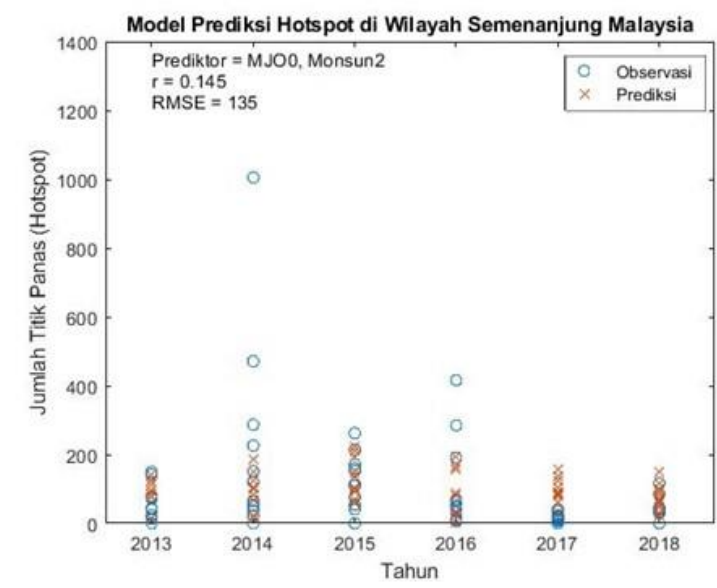

Gambar 5. Model prediksi titik panas (hotspot) di wilayah Semenanjung Malaysia.

Pada Gambar 5, dari keempat jenis variabel bebas atau prediktor (Osean-atmosfer) yang digunakan terlihat hanya prediktor MJO 0 dan Mons 2 yang berpengaruh terhadap kejadian munculnya hotspot.

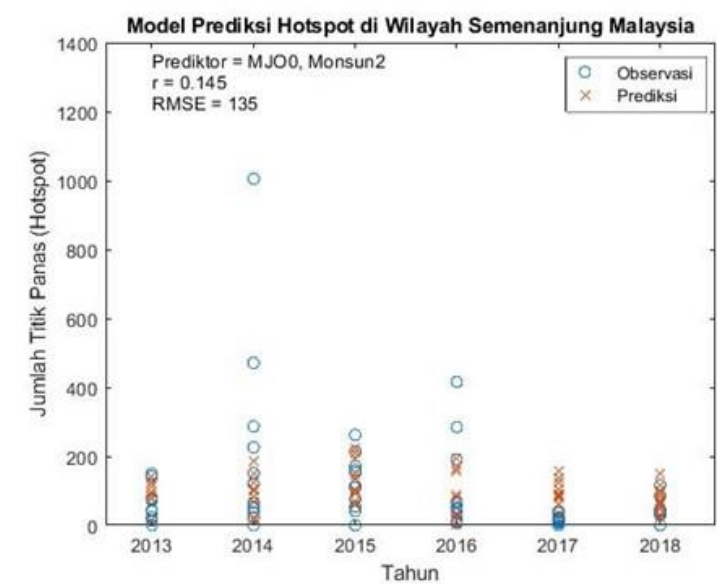

Gambar 6. Model prediksi titik panas (hotspot) di wilayah Sabah-Sarawak.

Pada Gambar 6, dari keempat jenis variabel bebas atau prediktor (fenomena atmosfer) yang digunakan terlihat hanya prediktor MJO 0 dan IOD 2 yang berpengaruh terhadap kejadian munculnya hotspot.

Berdasarkan dari kedua model prediksi Semenanjung Malaysia dan Wilayah Sabah dan Sarawak hanya beberapa range data prediksi dan data observasi hotspot yang berimpit (memiliki kesesuaian) dan sebagian besar tidak berimpit atau hampir mendekati.

Kemudian untuk mencermati kembali keakuratan prediksi, maka dapat dilakukan analisis diagram tebar, seperti pada Gambar 7. Model prediksi dari 4 wilayah di Kawasan Asia Tenggara bagian Selatan yang telah diperoleh dari hasil sebelumnya diuji kembali melalui tebaran data terhadap Line of Best Fit atau Perfect Forecast Line (garis prediksi terbaik) yang dimanifestasikan oleh garis lurus (garis diagonal) yang membentuk sudut $45^{\circ}$ di dalam kotak diagram. Semakin banyak tebaran data yang mendekati atau pun berimpit dengan perfect forecast line, maka semakin tinggi kualitas dan besar akurasi prediksi. Demikian pula sebaliknya, semakin banyak tebaran data yang menjauhi perfect forecast line, maka 
semakin rendah kualitas dan kecil akurasi prediksi.

Adapun 4 diagram tebar tersebut menunjukkan bahwa masing-masing wilayah memiliki tebaran titik data yang berbeda terhadap perfect forecast line.

Diagram Tebar Data Observasi dan Data Prediksi Titik Panas (Hotspot)

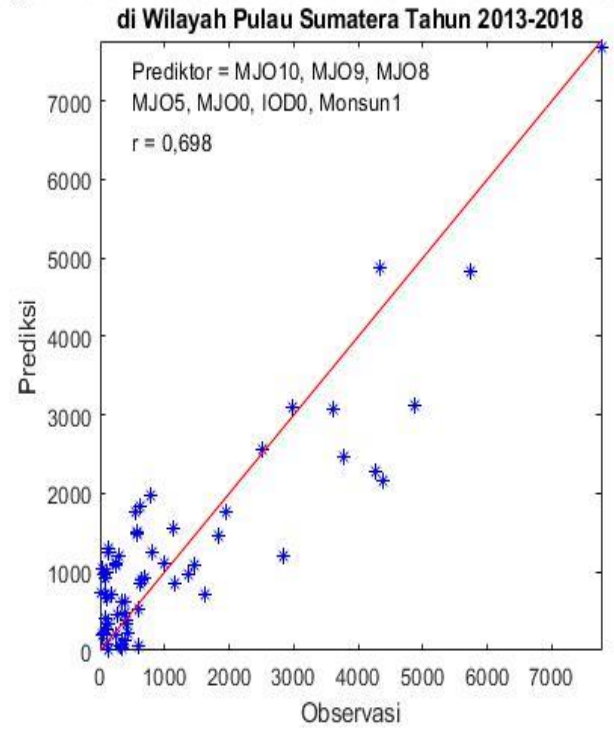

Diagram Tebar Data Observasi dan Data Prediksi Titik Panas (Hotspot) di Wilayah Semenanjung Malaysia Tahun 2013-2018

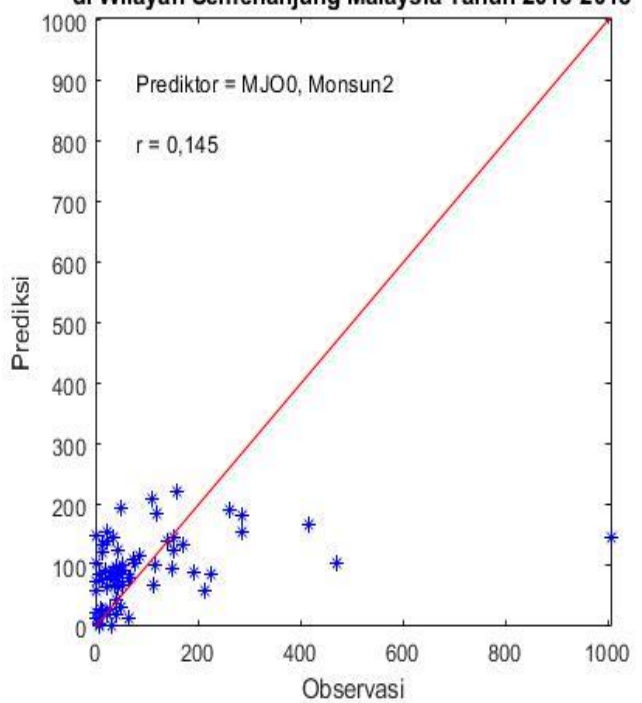

Perbedaan tersebut mengindikasikan bahwa terdapat pula perbedaan nilai korelasi maupun jenis dan jumlah prediktornya. Oleh karena itu, uji diagram tebar ini terhadap 4 model prediksi sebelumnya menunjukkan adanya kesesuaian (hasil yang sama).

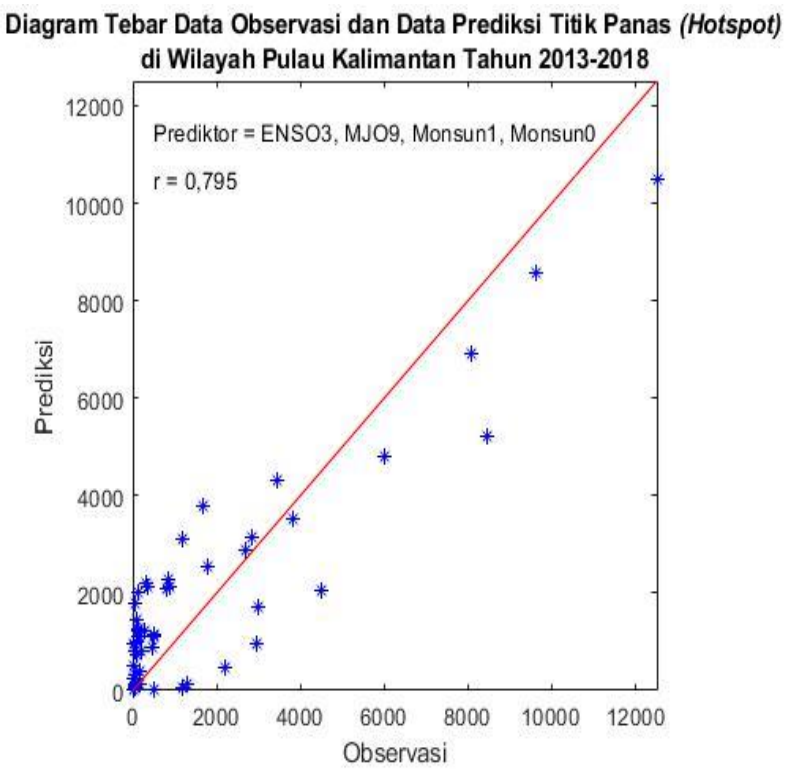

Diagram Tebar Data Observasi dan Data Prediksi Titik Panas (Hotspot) di Wilayah Sabah dan Sarawak Tahun 2013-2018

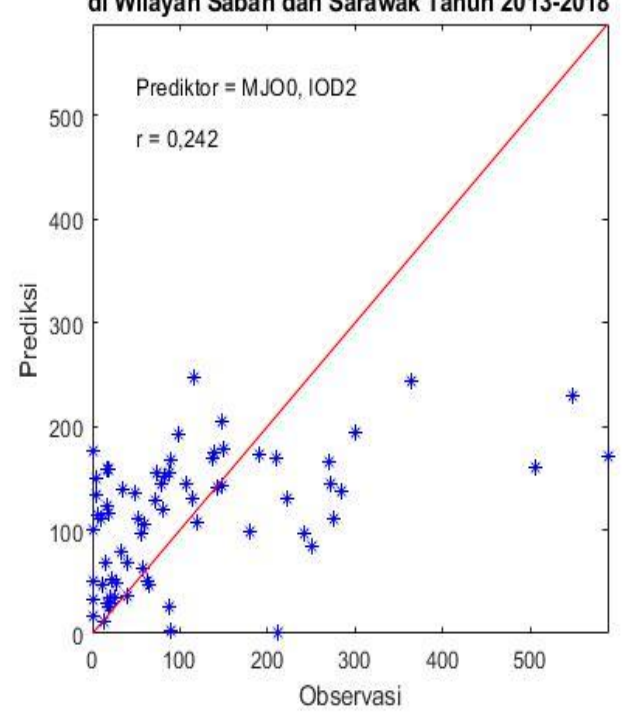

Gambar 7. Diagram tebar hasil prediksi terhadap observasi titik panas (hotspot) keempat wilayah di Kawasan Asia Tenggara bagian Selatan.

\section{Hasil Verifikasi Prediksi Model Statistik}

Hasil Korelasi Pearson dan RMSE dari akurasi prediksi hotspot diperlihatkan pada tabel berikut. 
Tabel 5. Tabel metrik Korelasi Pearson dan RMSE prediksi titik panas (hotspot).

\begin{tabular}{|c|c|c|c|c|}
\hline No & Wilayah & Prediktor & $\begin{array}{l}\text { Korelasi } \\
\text { Pearson }\end{array}$ & $\begin{array}{c}\text { RMSE } \\
\text { (hotspot) }\end{array}$ \\
\hline 1 & Sumatera & $\begin{array}{l}\text { MJO 10, } \\
\text { MJO 9, } \\
\text { MJ0 8, } \\
\text { MJO 5, } \\
\text { MJO 0, } \\
\text { IOD 0, } \\
\text { Mons 1 }\end{array}$ & 0,698 & 908 \\
\hline 2 & Kalimantan & $\begin{array}{l}\text { ENSO 3, } \\
\text { MJO 9, } \\
\text { Mons 1, } \\
\text { Mons 0 }\end{array}$ & 0,795 & 1150 \\
\hline 3 & $\begin{array}{l}\text { Semenanjung } \\
\text { Malaysia }\end{array}$ & $\begin{array}{l}\text { MJO 0, } \\
\text { Mons } 2\end{array}$ & 0,145 & 135 \\
\hline 4 & $\begin{array}{l}\text { Sabah dan } \\
\text { Sarawak }\end{array}$ & $\begin{array}{l}\text { IOD 2, } \\
\text { MJO } 0\end{array}$ & 0.242 & 113 \\
\hline
\end{tabular}

\section{Analisa Hasil Berdasarkan Faktor Interaksi Osean-Atmosfer}

\section{Pengaruh Prediktor ENSO terhadap Munculnya Titik Panas di Sumatera, Kalimantan, Semenanjung Malaysia dan Sabah-Sarawak}

Berdasarkan hasil analisis model Multiple Regression (MR) menggunakan metode regresi stepwise diperoleh model prediksi dengan sejumlah prediktor signifikan yang berpengaruh terhadap kejadian hotspot, salah satunya yaitu prediktor ENSO 3. Dalam pembahasan ini akan dibahas kejadian ENSO 3 bulan sebelum kejadian munculnya hotspot di wilayah Kalimantan. Pada saat terjadi ENSO, evolusi regional iklim yang disebabkan anomali El Nino terkait dengan penguatan interaksi atmosfer laut, dimodulasi oleh latar perubahan musim di wilayah Samudra Hindia Tenggara (SIO) selama SeptemberOktober-November (SON) periode tahun El Nino dan di wilayah Pasifik utara barat (WNP) selama periode Desember-JanuariFebruari (DJF) (Tangang and Juneng, 2004).

Karena evolusi ini, kondisi yang lebih kering dari biasanya tetap ada jadi kondisi inilah yang memicu terbentuknya hotspot di wilayah Pulau Kalimantan dan sering timbul dengan skala besar sehingga terjadi kebakaran hutan yang tidak terkendali. Dengan angin bertiup kencang ke arah barat laut selama periode ini, hampir terjadi kebakaran hutan yang berkepanjangan dan berskala besar di wilayah Kalimantan (Tangang et al., 2011).

Adapun kejadian ENSO kuat berdasarkan data observasi pada Gambar 1 dimana wilayah Kalimantan yang memiliki jumlah hotspot terbanyak yang mencapai 35.000 titik disebabkan oleh kejadian ENSO kuat pada tahun 2015, fenomena tersebut mempengaruhi variabilitas curah hujan dengan intensitas yang cukup kuat, dimana sepanjang bulan pada tahun 2015 terjadi periode defisit yang mengakibatkan terlambatnya musim hujan dan musim kemarau yang berkepanjangan dengan intensitas kekeringan dari normal sampai kering (Narulita dkk., 2019). Hal ini menunjukkan bahwa fenomena iklim global ENSO pada tahun tersebut, sangat mempengaruhi kejadian meningkatnya jumlah titik panas (hotspot) penyebab terjadinya kebakaran hutan yang tidak terkendali.

Pengaruh Prediktor MJO terhadap Munculnya Titik Panas di Sumatera, Kalimantan, Semenanjung Malaysia dan Sabah-Sarawak

Untuk prediktor MJO yang berpengaruh terhadap kejadian hotspot berdasarkan hasil dari metode regresi stepwise di wilayah Sumatera yaitu MJO 10, MJO 9, MJO 8, MJO 5, dan MJO 0, wilayah Kalimantan hanya MJO 9, kemudian wilayah Semenanjung Malaysia serta Sabah dan Sarawak memiliki prediktor yang sama yaitu MJO 0. Adapun pengaruh aktivitas MJO aktif dapat ditinjau dari besarnya anomali OLR (Outgoing Longwave Radiation) yakni jika semakin negatif nilai OLR di suatu wilayah mengindikasikan semakin banyaknya liputan awan di wilayah tersebut (MJO aktif). Sebaliknya, semakin positif nilai OLR menunjukkan semakin sedikit liputan awan di suatu 
wilayah (MJO tidak aktif) (Blegur dkk., 2019).

Oleh karena itu, ketika terjadi MJO tidak aktif (nilai indeks OLR positif) di wilayah yang dipengaruhi oleh Indeks MJO tadi yaitu Sumatera, Kalimantan, Semenanjung Malaysia, Sabah dan Sarawak maka kondisi cuaca menjadi cerah karena sedikitnya liputan awan atau pembentukan awan yang kurang signifikan. Sehingga terindikasi berpengaruh terhadap pembentukan hotspot jika terjadi di musim kemarau. Kemudian, apabila terjadi MJO aktif (indeks OLR negatif) di suatu wilayah yaitu ditandai dengan banyaknya liputan awan maka dapat memicu terbentuknya siklon tropis yang cenderung berkembang ketika MJO meningkatkan curah hujan. Karena penjalaran MJO berlangsung ke arah timur, maka wilayah aktivitas siklon tropis juga bergeser ke arah timur dari Samudera Hindia ke Samudera Pasifik (Madden and Julian, 1994). Sehingga, secara tidak langsung sebagian wilayah Indonesia dan Malaysia yang secara geografis letaknya berdekatan mendapatkan pengaruh dari keberadaan siklon tropis, salah satunya adalah bencana kekeringan. Hal ini terjadi karena keberadaan siklon tropis yang dekat dengan perairan wilayah Indonesia akan membuat massa uap air tertarik dari perairan wilayah Indonesia menuju ke titik pusat tekanan rendah dari sistem siklon tropis tersebut sehingga udara di wilayah tersebut menjadi cukup kering dan sulit terbentuknya awan. Akibat dari intensitas kekeringan yang cukup tinggi ditambah perilaku masyarakat yang kurang bertanggung jawab dalam melakukan aktivitas pembukaan lahan (land clearing), maka tingkat kekeringan menjadi semakin parah sehingga terjadi peningkatan jumlah hotspot. (Syaifullah, 2015). Berdasarkan pernyataan sebelumnya, fenomena MJO negatif juga dapat diindikasikan berpengaruh terhadap pembentukan hotspot.
Pengaruh Prediktor IOD terhadap Munculnya Hotspot di Sumatera, Kalimantan, Semenanjung Malaysia dan Sabah-Sarawak

Untuk prediktor IOD yang berpengaruh terhadap kejadian hotspot berdasarkan hasil dari metode regresi stepwise di wilayah Sumatera yaitu IOD 0 (pengaruh fenomena IOD pada bulan terjadinya hotspot) dan prediktor IOD 2 (pengaruh fenomena IOD 2 bulan sebelum kejadian hotspot) di wilayah Sabah dan Sarawak. Ketika terjadi IOD positif fenomena yang teramati adalah musim kemarau panjang yang terjadi di wilayah Indonesia khususnya di wilayah Sumatera yang berdekatan dengan Samudera Hindia. Salah satu contohnya yaitu pada penelitian yang dilakukan oleh Tjasyono dkk. (2008) yang menyatakan bahwa kejadian IOD sangat berdampak terhadap curah hujan di wilayah Sumatera Barat. Ketika terjadi IOD (+), wilayah Sumatera Barat pada umumnya memiliki curah hujan di bawah normal yaitu kurang dari $85 \%$ dari rata-rata curah hujan pada periode normalnya (rata-rata selama 30 tahun) dengan kata lain fenomena IOD (+) menyebabkan terjadinya kekeringan sehingga memicu terbentuknya hotspot. untuk wilayah Sabah dan Sarawak yang terletak di sebelah utara Pulau Kalimantan juga kerap mengalami dampak dari IOD ini. Oleh karena itu, fenomena IOD positif dapat diindikasikan berpengaruh terhadap kejadian hotspot.

\section{Pengaruh Prediktor Monsun terhadap Munculnya Hotspot di Sumatera, Kalimantan, Semenanjung Malaysia dan Sabah-Sarawak}

Untuk prediktor Monsun yang berpengaruh terhadap kejadian hotspot di wilayah Sumatera yaitu Monsun 1 (1 bulan sebelum kejadian hotspot), wilayah Kalimantan adalah Monsun 1 dan Monsun 0 (Pada bulan terjadinya hotspot), kemudian untuk wilayah Semenanjung Malaysia yaitu Monsun 2 (2 bulan sebelum kejadian hotspot). Fenomena Monsun yang terjadi di 
Indonesia terutama di musim kemarau praktis bersamaan dengan musim Monsun Timur atau Monsun Australia (Hermawan dan Witono, 2012). Kebakaran lahan dan hutan biasanya terjadi pada bulan-bulan kering terutama yang paling parah di Kalimantan dan Sumatera, yaitu pada bulan Mei hingga Oktober, pada bulan tersebut merupakan periode curah hujan dengan intensitas terendah, karena pada periode ini, pergerakan angin Monsun Timur melewati wilayah yang sebagian besar adalah gurun di Australia (Arini, 2014). Oleh karena itu, prediktor Monsun diindikasikan cukup berpengaruh terhadap kejadian munculnya hotspot di Sumatera dan Kalimantan serta di wilayah Semenanjung Malaysia karena secara Geografis letaknya berada di satu kawasan antara Pulau Sumatera dan Kalimantan sehingga memiliki iklim yang sama.

\section{Kesimpulan}

Secara keseluruhan dari hasil analisis model prediksi hotspot di kawasan Asia Tenggara Bagian Selatan, untuk wilayah Sumatera menghasilkan tujuh prediktor signifikan yang terkait dengan munculnya hotspot, yaitu IOD 0, MJO 0, MJO 9, MJO 10, Mons 1, MJO 8, dan MJO 5. Dengan prediktor yang paling berpengaruh dari ketujuh prediktor tersebut, yaitu IOD 0 dengan koefisien standar (beta) sebesar 2,02, yakni fenomena IOD khususnya fenomena IOD (+) penyebab terjadinya musim kering ini beberapa kali terjadi di wilayah Pulau Sumatera karena letaknya berdekatan langsung dengan samudera hindia sehingga iklimnya juga dipengaruhi oleh lautan di dekatnya. Untuk wilayah Kalimantan menghasilkan empat prediktor signifikan yang terkait dengan munculnya hotspot, yaitu MJO 9, Mons 1, Mons 0, dan ENSO 3. Dengan prediktor yang paling berpengaruh dari keempat prediktor tersebut, yaitu MJO 9 dengan koefisien standar (beta) sebesar -1,98. Untuk wilayah Semenanjung Malaysia hanya menghasilkan dua prediktor signifikan yang terkait dengan munculnya hotspot, yaitu Mons 2 dan MJO 0. Mons 2 merupakan prediktor yang paling berpengaruh dengan koefisien standar (beta) sebesar 0,28. Dan yang terakhir untuk wilayah Sabah dan Sarawak juga hanya menghasilkan dua prediktor signifikan yang terkait dengan munculnya hotspot, yaitu IOD 2 dan MJO 0. MJO 0 merupakan prediktor yang paling berpengaruh dengan nilai koefisien standar (beta) sebesar 0,43. Untuk indeks MJO dan Monsun yang paling berpengaruh di Wilayah Kalimantan, Semenanjung Malaysia serta Sabah dan Sarawak. Kedua fenomena tersebut seringkali melintas di ketiga wilayah tersebut pada bulan-bulan terjadinya musim kering, sehingga diindikasikan dapat mempengaruhi munculnya hotspot.

Berdasarkan hasil uji verifikasi yang dilakukan terhadap model prediksi hotspot, nilai Korelasi Pearson tertinggi berada di wilayah Kalimantan yaitu sebesar 0,795. Kemudian wilayah Sumatera dengan nilai korelasi sebesar 0,698. Selanjutnya untuk wilayah Semenanjung Malaysia serta Sabah dan Sarawak hanya menghasilkan nilai korelasi sebesar 0,145 dan 0,242, yakni nilai tersebut menunjukkan korelasi yang lemah antara prediktor dengan hotspot. Selanjutnya nilai kesalahan RMSE untuk masing-masing wilayah diperoleh sebesar 908 hotspot di wilayah Sumatera, 1150 hotspot di wilayah Kalimantan, 135 hotspot di wilayah Semenanjung Malaysia, dan nilai RMSE sebesar 113 hotspot di wilayah Sabah dan Sarawak.

Untuk mendapatkan hasil analisis yang lebih akurat maka penelitian selanjutnya dapat menggunakan metode pengamatan hotspot yang dapat membuat klasifikasi hotspot berdasarkan temperaturnya, sehingga dapat dibedakan hotspot, lahan yang sudah terbakar, yang akan terbakar, yang sedang terbakar dan dipadamkan. 


\section{Ucapan Terimakasih}

Terima kasih saya ucapkan kepada penyedia situs ASMC http://asmc.asean.org/asmc-haze-hotspotmonthly/, situs NOAA https://www.cpc.ncep.noaa.gov/data/indice s, situs Jianping Li's Homepage Monsoon (AUSMI and SASMI) GCESS dan situs KNMI Climate Explorer indices https://climexp.knmi.nl/getindices yang telah menyediakan data yang dengan mudah dapat diakses secara gratis.

\section{Daftar Pustaka}

Arini, E.Y. 2014. Simulasi Curah Hujan Kalimantan Menggunakan Regional Climate Model 4 (REGCM4) Saat El Nino Southern Oscillation (ENSO). Skripsi, Bogor: Institut Pertanian Bogor.

ASMC, 2020. http://asmc.asean.org/asmchaze-hotspot-monthly/. Diakses pada 9 Maret 2020.

Bappenas. 2016. Grand Design Pencegahan Kebakaran Hutan Kebun dan Lahan. Jakarta: Bappenas.

Blegur, T.Y., Daka, S., Fuadz, M., Liliana, R.R. dan Wicaksono, M.C.W. 2019. Buletin Informasi Meteorologi Edisi V Bulan Mei 2019. Alor: Stamet Mali.

BMKG. 2017. BULETIN Cuaca dan Iklim Maritim. Jakarta: BMKG Maritim.

BNPB. 2013. Rencana Kontinjensi Nasional Menghadapi Ancaman Benana Asap Akibat Kebakaran Hutan dan Lahan. Jakarta: BNPB.

Chang, C-P., Wang, Z., McBride, J. and Liu, C. 2005. Annual cycle of Southeast Asia-Maritime Continent Rainfall and Asymmetric Monsoon Transition. Journal of Climate. 18: 287-301.

Endrawati. 2016. Analisis Data Titik Panas (Hotspot) dan Areal Kebakaran Hutan dan Lahan Tahun 2016. Jakarta: KLHK.
Erwinsyah. 2017. Pengaruh Jumlah Penduduk, Produk Domestik Bruto Dan Tenaga Kerja Kehutanan Terhadap Luas Kebakaran Hutan Dan Lahan di Indonesia. Jurnal Populis. Vol. 2 (3) :321-328.

Fahrmeir, L., Kneib, T., Lang, S. and Marx, B. 2013. Regression: Models, Methods and Applications. Switzerland: Springer Publication 2013.

Hacker, E. C., and Hastenrath, S. 1985. Mechanisms of Java Rainfall Anomalies. Monthly weather review. 114: 745-757.

Hermawan, E. dan Witono, A. 2012. Penerapan Metode Analisis Komposit Dalam Menentukan Terjadinya Perbedaan Musim Kemaraul Penghujan Di Kab. Kukar, Bulungan Dan Berau Provinsi Kalimantan Timur Secara Serempak (Simultan). pp. 84-91. ISBN 978-979-1458-64-1.

Iizuka, S., Matsuura, T., \& Yamagata, T. 2000. The Indian Ocean SST dipole simulated in a coupled general circulation model. Geophysical Research Lett. 27: 3369- 3372.

Jianping Li's Homepage, 2020 http://ijp.gcess.cn/dct/page/l. Diakses pada 9 Maret 2020.

KNMI Climate Explorer, 2020. https://climexp.knmi.nl/getindices. Diakses pada 9 Maret 2020.

Krishnamurti, T.N. and Bhalme, H.N. 1976. Oscillations of a Monsoon System. Part I. Observational Aspects. J. Atmos. Sci. 33: 19371954.

Madden, R.A. and Julian, P.R. 1994. Observations of the 40- 50-day Tropical Oscillation A review, Mon. Weather Rev. 122: 814- 837.

Maloney, E. and Hartmann, D. 2000. Modulation of Eastern North Pacifichurricanes by the MaddenJulian Oscillation. J. Climate. 13: 1451-1460. 
Mulyana, E. 2002. Analisis Angin Zonal di Indonesia Selama Periode ENSO. Jurnal Sains \& Teknologi Modifikasi Cuaca. Vol. 3(2): 115 120.

Narulita, Ida., Rahayu, R., Kusratmoko, E., Supriatna. dan Djuwansah, M.R. 2019. Ancaman Kekeringan Meteorologis di Pulau Kecil Tropis akibat Pengaruh El-Nino dan Indian Ocean Dipole (IOD) Effects, case study: Bintan Island. Jurnal lingkungan dan bencana geologi. 10(3): $\quad 127$

138. http://doi.org/10.34126/jlbg.v 10i3.252.

NOAA.2019.https://www.cpc.ncep.noaa.g ov/data/indices/. Diakses pada 9 Agustus 2019.

Nur, Rusnianti. 2017. Verifikasi Model Prediksi Nilai Titik Panas (Hotspot) di Kalimantan. Skripsi, Makassar: Universitas Hasanuddin.

Peraturan Menteri Kehutanan Nomor: P. 12/Menhut-Ii/2009 tentang Pengendalian Kebakaran Hutan. Jakarta.

Prayoga, M. B. R., Ardila, Y., dan Della A. K. 2017. Analisis Korelasi Kerapatan Titik Api Dengan Curah Hujan Di Pulau Sumatera Dan Kalimantan. Jurnal Sains \& Teknologi Modifikasi Cuaca, Vol. 18(1): $\quad 17 \quad-\quad 24.5$. https://doi.org/10.29122/jstmc.v18i $\underline{1.2037}$

Saji, N.H., and Yamagata, T. 2003. Possible impacts of Indian Ocean Dipole mode events on global climate. Climate Research. 25:151159.

Saji N.H., Goswami, B.N., Vinayachandran, P.N. and Yamagata, T. 1999. A Dipole Mode in The Tropical Indian Ocean. in Macmillan Magazines Ltd, Nature, Vol.401. http://doi.org/10.1038/43854

Syaifullah, M.D. 2015. Siklon Tropis, Karasteristik Dan Pengaruhnya Di
Wilayah Indonesia Pada Tahun 2012. Jurnal Sains dan Teknologi Modifikasi Cuaca. 16(2): 61 - 71 . http://doi.org/10.29122/jstmc.v16i2 .1048 .

Tacconi, L. 2003. Kebakaran Hutan di Indonesia: Penyebab, Biaya dan Implikasi Kebijakan. Bogor: Cente for International Forestry Research (CIFOR).

Tangang, F.T., Xia, C., Qiao, F., Juneng, L. and Shan, F. 2011. Seasonal circulations in the Malay Peninsula Eastern continental shelf from a wave-tide-circulation coupled model. Ocean Dynamics. http://doi.org/10.1007/s10236-0110432-5.

Tangang, F.T. and Juneng, L. 2004. Mechanisms of Malaysia rainfall anomalies. Journal of Climate. 17(18):

3615-3621. https://doi.org/10.1175/15200442(2004)017.

Tjasyono, B.H.K., Lubis, A., Juaeni, I., Ruminta, Harijono S.W.B. 2008. Dampak Variasi Temperatur Samudera Pasifik dan Hindia Ekuatorial terhadap Curah Hujan di Indonesia. Jurnal Sains Dirgantara, Vol. 5(2): 83-95.

Trenberth, K.E. 1997. The Definition El Nino. Bulletin of the American Meteorologicaal Society. 78(12): 2771-2777.

Vinayachandran, P.N., Iizuka, S. and Yamagata, T. 2002. Indian Ocean dipole mode events in an ocean general circulation model. DeepSea Res. PI.D. 49: 1573-1596.

Webster P. J., Magaña, V. O., Palmer, T. N., Shukla, J., Tomas, R. A., Yanai, M. and Yasunari, T. 1998: Monsoons: processes, predictability, and the prospects for prediction. Journal of Geophysical Research. 103(C7): 14451-14510 